\title{
Salt exploitation in the later prehistory of the Carpathian Basin
}

\author{
Anthony Harding \\ Department of Archaeology, University of Exeter, UK \\ a.f.harding@exeter.ac.uk
}

\begin{abstract}
Salt is a necessity for humans and animals, today as in the ancient past. The ways in which salt was produced in ancient times vary from area to area, and could use briquetage, deep mining (as at Hallstatt), or the technique specific to Transylvania, based on wooden troughs, perforated in the base. How these troughs functioned is still uncertain. In the Iron Age a different technique was employed, involving deep shafts dug down to the rock salt surface. As well as technological considerations, it is crucial to understand the social and economic importance of salt in the ancient world.

IZVLEČEK - Tako kot sol potrebujemo danes, so jo potrebovali ljudje in živali tudi v preteklosti. Pridobivanje soli se je v preteklosti med regijami razlikovalo. Lahko je vključevalo tehniko briketiranja, rudarjenje (kot v Halštatu) ali pa posebno tehniko, značilno za Transilvanijo, ki je temeljila na lesenih, na dnu perforiranih koritih. Še vedno ni jasno, kako so ta korita delovala. V̌̌elezni dobi je bila uporabljena drugačna tehnologija. Vključevala je kopanje globokih jaškov do plasti kamene soli. Poleg poznavanja tehnologij pridobivanja soli, je potrebno tudi razumevanje družbenega in gospodarskega pomena soli $v$ preteklosti.
\end{abstract}

KEY WORDS - salt; Carpathian Basin; briquetage; mining; wooden troughs

\section{Introduction}

Common salt, sodium chloride, is widely recognised as a crucial commodity for ancient communities, just as it is for modern ones. Although in our modern world a very small proportion of the salt produced is used in the preparation and consumption of food, it is that use which we tend to think of when we speak of salt. In practice, it is for industrial purposes and road clearance in winter that most salt is used today. In the ancient past, things were very different. There were some industrial applications of salt, such as tanning, but in all likelihood by far and away the most significant application was in the storage and preservation of foodstuffs. Today, and in the recent past, even developed societies use salt for food preservation; in peasant societies, especially those without electricity and therefore refrigerators, salt is crucial for people to store cheese, vegetables, and meat. It has other uses in such communities too, for in- stance in therapeutic purposes for both humans and animals.

Humans and animals need a certain intake of salt in order to preserve the metabolic balance of the body; without it, serious health problems can occur. While the minimum needed for human health is relatively small ( $2 \mathrm{~g}$ per adult per day is regarded as a reasonable figure), when one adds in the needs of animals, the amounts required become more substantial. Taken all in all, we can presume that in prehistory, as in early history, steps were taken to ensure the availability of salt by all communities - but especially by those who were not fortunate enough to live on or near salt sources.

This raises important archaeological questions. If salt was moved around Europe, it was a trade com- 
modity; and trade (or more accurately exchange) was an important part of the ancient economy, whether in the Bronze Age, the Iron Age, or any other period. The questions therefore include this one: can we identify not only salt production methods and places in prehistory, but also the evidence for its movement around Europe?

There could in theory be two ways of tackling that question: one, by archaeological means, such as identifying the containers in which the salt was moved; the other by analytical means, by identifying the compositional pattern of particular salt sources. Unfortunately, neither method is currently possible, at least in the Carpathian Basin. Containers for salt have not been found from prehistoric contexts, other than the coarse

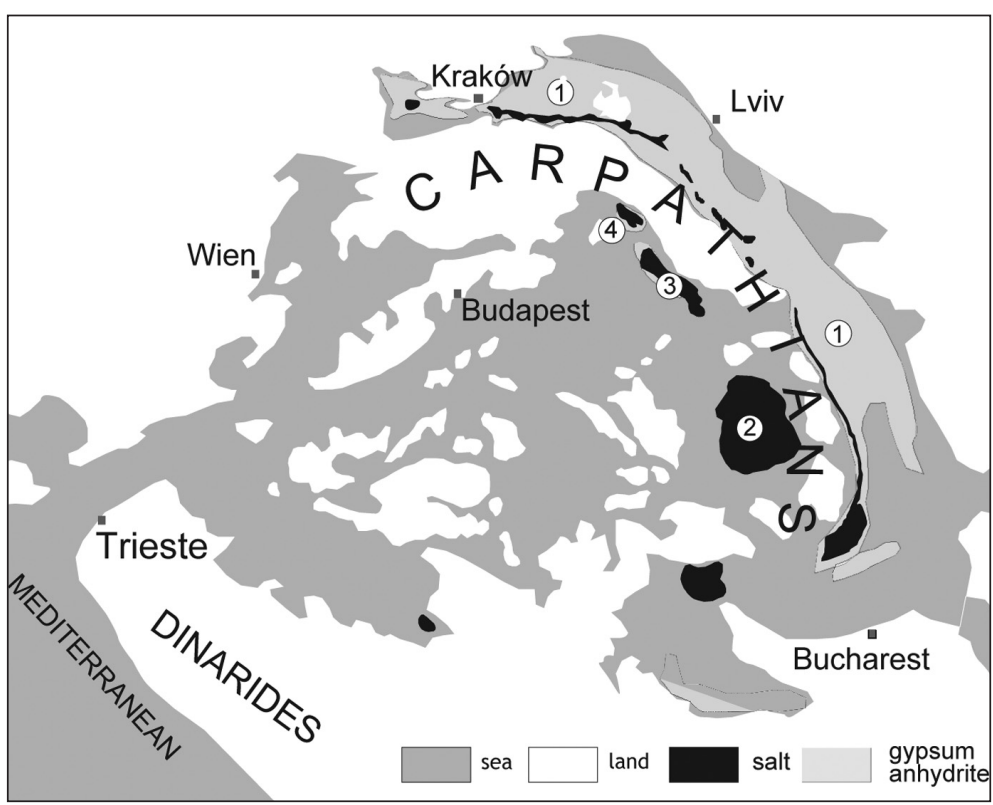

Fig. 1. Distribution of salt, gypsum and anhydrite in the central Paratethys Sea during the 'Badenian salinity crisis'. 1 Carpathian Foredeep. 2 Transylvanian Basin. 3 Transcarpathian Basin. 4 East Slovakian Basin (after Bukowski 2013). pottery known as briquetage (see below); nor is it currently possible to separate salt sources analytically except within very large limits, and at present the consensus among chemists and geologists is that it will not be possible to go to the level that archaeologists would find useful, the separation of individual sources within a single region. In the analysis of common salt, the chlorine signal is so dominant that tracing impurity patterns, or isotopic variations in other elements, becomes impossible. In addition, salt is highly soluble, so it neither survives in solid form (with rare exceptions, below) nor as an element in other artefacts such as pottery or bone.

\section{Salt in the Carpathian Basin}

Many parts of the Carpathian Basin are rich in salt, which geologically speaking is an evaporite (a mineral created through the evaporation and chemical precipitation of salts contained in seawater or salt lakes). This applies particularly to areas within the Carpathian mountain ring (or just outside it, as with Moldavia, ${ }^{1}$ Galicia or Little Poland), and especially to Transylvania. Thus many localities in eastern and northern Slovakia have salt, as do many parts of central, northern and eastern Romania. There is also salt further south, at Tuzla in Bosnia, and one should not forget the sources in the eastern Alps, most notably Hallstatt and the Dürrnberg near Hallein, though strictly speaking these do not lie in the Car- pathian Basin. But they were undoubtedly significant for areas within the Basin, notably present-day Hungary, which today has no salt at all.

Salt deposits are present in four main areas (Fig. 1): the Carpathian Foredeep (from Kraków through Ukraine to Moldavia), Transylvania (the Transylvanian Basin), the Transcarpathian Basin (the Maramures and adjacent areas of Ukraine north of the Tisza) and the East Slovakian Basin. It is primarily the latter three that concern us here.

The salt deposits of the Carpathian Basin were described recently by Krzysztof Bukowski (Bukowski 2013). The deposits are of Miocene age, and result from the presence of the Paratethys Sea, which covered much of central and eastern Europe, including what is today the Black Sea. The salt arose as a consequence of the 'Badenian Salinity Crisis', a major climatic and environmental change that brought about a continuous series of evaporite deposits (not only salts, but also gypsum and anhydrite). The salt is apparent not only in rock massifs, but also in the brine springs that occur throughout the area. Precipitation (i.e. rain) passes through the ground and dissolves the salts, which then flow back to the surface in the form of salt springs. It is the brine from these springs that has been so important for much of the exploitation we see in historical and modern times. 


\section{Archaeological evidence for salt exploitation in the Carpathian Basin}

Traditionally, salt archaeology has concentrated on two forms of exploitation: evaporating brine or seawater, and deep mining. The latter is mainly known from the Austrian Alps (Hallstatt and Hallein), and until fairly recently was thought to be a phenomenon of the Iron Age; in the last 30 years it has become apparent that there was a major Bronze Age phase of exploitation at Hallstatt as well (Kern et al. 2009). These sources are not our main area of concern here, however. The exploitation of salt water can take place either in lagoons or salt lakes, which leave little or no archaeological trace, or by artificial means of evaporating the brine, through the use of heat. In the latter case, the brine was placed in coarse ceramic containers known as briquetage, and the containers were placed on furnaces or ovens. Originally defined at the massive Iron Age sites in Lorraine, eastern France, briquetage also turns up elsewhere in western Europe in Bronze and Iron Age contexts, notably in Germany.

Within the Carpathian Basin, there are few (if any) indisputable finds of briquetage, of any age. There are, however, notable finds in Moldavia of Neolithic date (Andronic 1989; Ursulescu 1977), and ceramics thought to be briquetage near Wieliczka in southern Poland (Jodtowski 1971), and in Bosnia (Tasić 2002), of similar age. Curiously, such finds are not repeated in later periods, nor inside the Basin itself; the situation has recently been discussed by Eszter Bánffy (2013). So, if not through evaporation using briquetage, what? How was salt obtained in the Carpathian Basin in prehistory?

The first answer to this question would be that solar evaporation helped to provide at least some of what was required. In the heat of summer, the numerous salt springs and streams dry out, leaving a crust of salt crystals on the surface; these can be picked off and used, though a further wash in fresh water improves the taste of the salt.

Waiting for the sun to evaporate salt water could be avoided by utilising other means; in many parts of temperate Europe, including the Carpathian
Basin, the sun would only be hot enough at the height of summer to produce any reasonable quantity of salt. Alternative methods would have been necessary. Here we come to a rather extraordinary phenomenon that has only become properly known in the last ten years. The story has been told in detail before, but a short summary of the situation will suffice here. In the early $19^{\text {th }}$ century, a curious set of wooden objects was found in a salt mine shaft in what is today Transcarpathian Ukraine, at the time part of Hungary. The finds included a ladder, ropes, mallets and, most notably, a hollowed out wooden trough with a set of perforations in the base which were filled with wooden pegs or plugs. The finds were described 60 years later (Preisig 1877), and illustrated in the catalogue of the Hungarian State Geological Institute, published in 1909 (Vezetó 1909). After that, they disappeared from sight, only being rediscovered in 2008 in the Central Mining Museum in Sopron, western Hungary, where they have now been studied and republished (Harding 2011).

Meanwhile a similar trough and other wooden objects were found in the 1930s at Valea Florilor, north of Turda in Transylvania (Maxim 1971). These finds came into particular prominence when work began on the Băile Figa site in northern Transylvania near Beclean; a trough of the same kind was extracted in
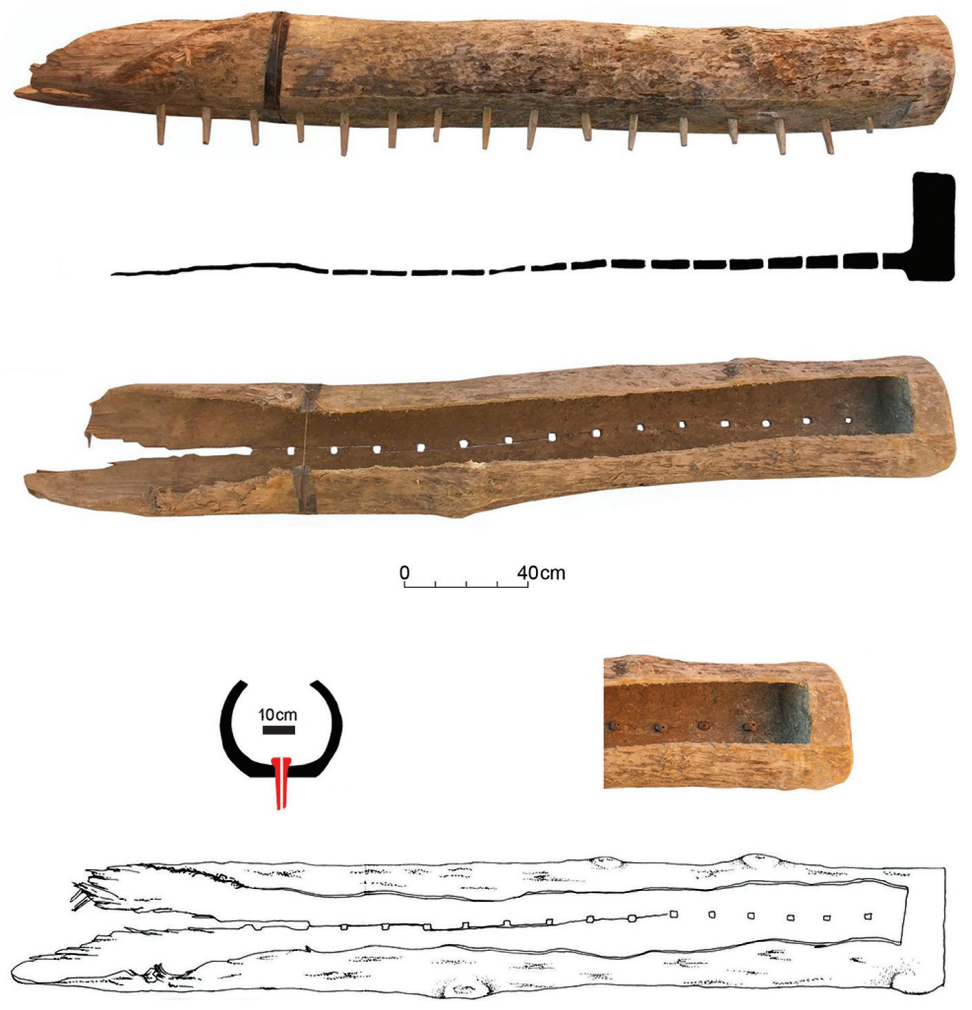

Fig. 2. Wooden trough from Băile Figa, Beclean. 
2005 by the local museum geologist, followed by further examples from excavation starting in 2007 (Chintăuan 2005; Harding, Kavruk 2013) (Fig. 2). Subsequently, another object of this kind was discovered not far from Figa at Caila, and there are indications that the same technology was used in other places in the same area. There are thus six sites now known where the trough technique was used; all lie in the Carpathian Basin, and most lie within Transylvania. At present, there is no indication that this technology was used further east, in Moldavia, or further north, in Galicia and Poland, but if it was a successful method of obtaining salt, it would seem unlikely that it was restricted to the relatively small area that is currently known to be its home. Especially in Moldavia there other indications of ancient salt working that closely resemble what is known from Transylvania (Monah 2002); it might be surprising, therefore, if the trough technique does not eventually turn out to have been used there as well.

The troughs vary in detail, but can be up to $3 \mathrm{~m}$ in length; none of those that survive is intact, so it is not certain that both ends were enclosed (Harding, Kavruk 2013.194-198). The perforations in the base can be round or square, the pegs shaped accordingly. There are indications from the dating evidence that round holes gave way to square ones, presumably because the pegs in round holes could twist around and become separated from the trough; square pegs in square holes could not rotate. The pegs that survive are themselves perforated, and in a few instances the perforation is known to have been filled either with twisted cord, or with a wooden needle. At Figa, one of the troughs was found partially supported by posts (Fig. 3); thus it would appear that they were raised up above the ground surface on some kind of structure.

As well as the troughs, many other wooden installations were used. The excavation evidence from Figa is particularly rich in this respect, though still hard to understand in detail. A common feature was the creation of roughly circular areas varying in size from $2-3 \mathrm{~m}$ across to as much as 10 $\mathrm{x} 13 \mathrm{~m}$, enclosed by wattle fences; these were probably brine storage ponds (Fig. 4). A complex sequence of constructions using both wattle and split oak timber was also present at Figa, though how these worked is not yet clear. What is clear, however, is that the technology is mainly Bronze Age: of the 66 radiocarbon dates so far obtained, more than 40 fall between 1600 and 800 calBC (Harding, Kavruk 2013. 116-117). A very few are earlier (and there is Early Bronze Age pottery from the site that may corroborate this), and some are later, falling into the Dacian Iron Age (more of this below).

What, then, was the technology involved? Here, different opinions have been expressed, and there is no certainty about the matter, though some facts may be stated. The excavations at Figa and the indications from early finds have shown that the troughs do not seem to come singly, but in pairs or groups. In Trench $\mathrm{XV}$ at Figa, for instance, five troughs have been found in or near one single area, four in a straight line (Cavruc et al. 2014); in Trench I, there are two troughs; at Valea Florilor, there seem to have been three. Thus whatever the technology involved, it probably utilised multiple troughs, either in parallel or in line. If the latter, they may have worked in sequence, perhaps to concentrate the salty water to the extent that salt crystals would form quickly, for easy removal by hand; if the former, the intention was presumably to maximise output.

The publisher of the very first trough to be discovered, Eduard Preisig, suggested that the function of the troughs was to allow water to drip slowly onto the rock salt, creating depressions in the rock surface, which would facilitate the removal of blocks of salt (Preisig 1877). This technique was recreated experimentally by my colleague Valeriu Kavruk and his team (Buzea 2010). After several attempts, it was

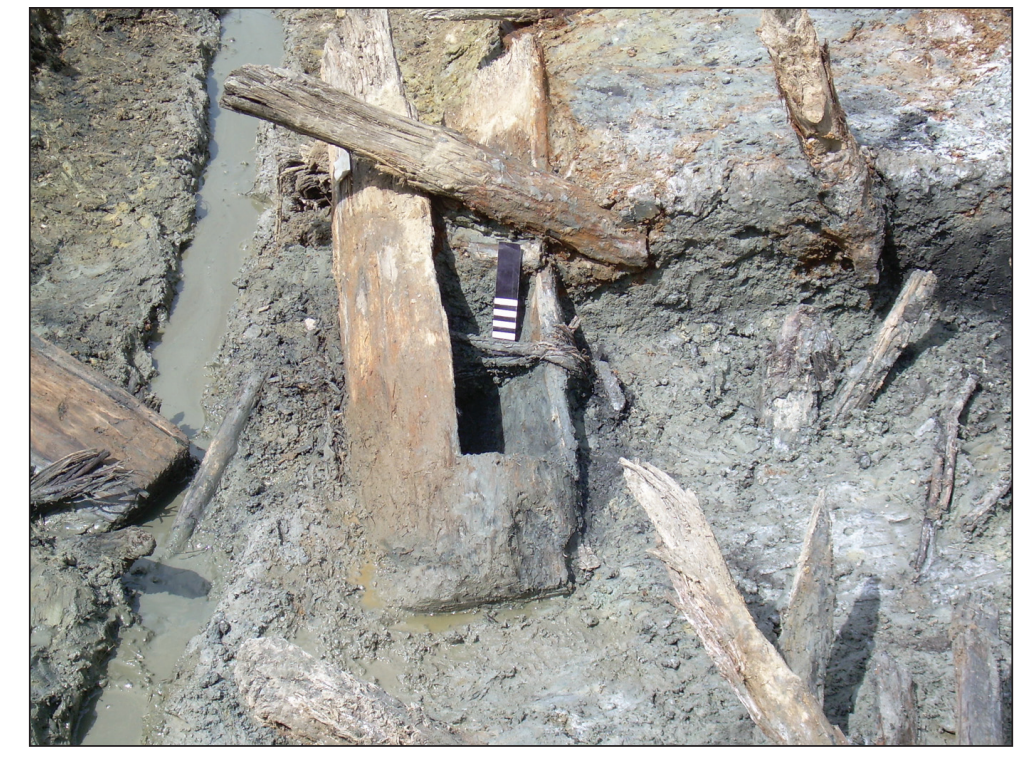

Fig. 3. Trough from Băile Figa as found, showing post supports. 
found to work satisfactorily, provided that fresh water was used, and the installation was allowed to run for several hours. At Figa, the rock salt is very hard and cannot easily be broken up by hand. Even modern cast-iron tools have difficulties in detaching more than small pieces of rock. So a method of speeding up the process would appear to be a solution to the problem, and perhaps gives an indication of how the troughs were used.

This does not, however, solve all the problems presented by the installations found at Figa and elsewhere. It does not, for instance, explain why the troughs should have been found in pairs or groups, unless this was

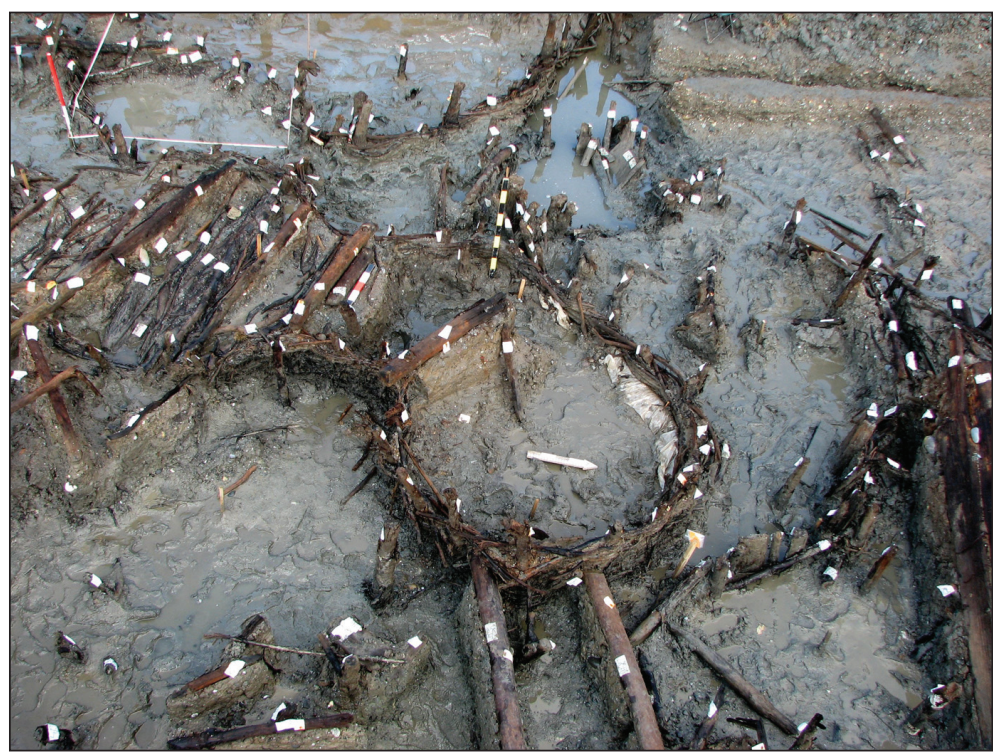

Fig. 4. Wattle fences around a possible brine storage pond at Băile Figa. simply a factor of several troughs having been used at once, or of one succeeding another as one went out of commission and another was needed in order to maintain the supply of salt. Nor does it explain the function of the wattle-framed ponds and other built constructions, which I have suggested above were created in order to store brine. Perhaps most likely is the idea that once pieces of rock had been broken off the parent body, they were put into the wattle ponds to dissolve, the brine thus concentrated then being used as it was or allowed to dry out to form crystals. The technique of turning rock salt into crystalline salt by dissolving it in water is known from other places, notably Hallstatt.

\section{The Iron Age and Roman periods}

ing. Some 14 of the 66 radiocarbon dates from Figa date to the Iron Age, so activity at the site in this period must have been more than cursory. It is not impossible, however, that the troughs continued to be used at the bottom of these shafts, though there is no evidence for this, and all the dated troughs belong to the Bronze Age.

At least one other site has definite evidence for Iron Age activity: Sânpaul in Harghita county, in the south-east of Transylvania (Harding, Kavruk 2013. 43-47). This locality was already known as the site of a Roman fort and vicus, and of a Roman altar referring to M. Caius Iulius Valentinus, who is described as conductor salinarum (Piso 2004-2005 (2007)). In a stream running down from a brine well lie timber posts; these have been dated (Fig. 6).

In the Iron Age, further technological innovations came into use at Figa. In the south of the site, shafts and pits were dug down to reach the rock salt, one of them being lined with split timbers placed one above the other to form a box-like construction; another was a simple pit (of unknown depth), access to which was by means of a ladder (Harding, Kavruk 2013.198-199) (Fig. 5). Since the bottom of these shafts lies below the present-day water table, it is not known how the salt was extracted at the working face, but presumably the intention was to obtain lumps of rock salt for later process-

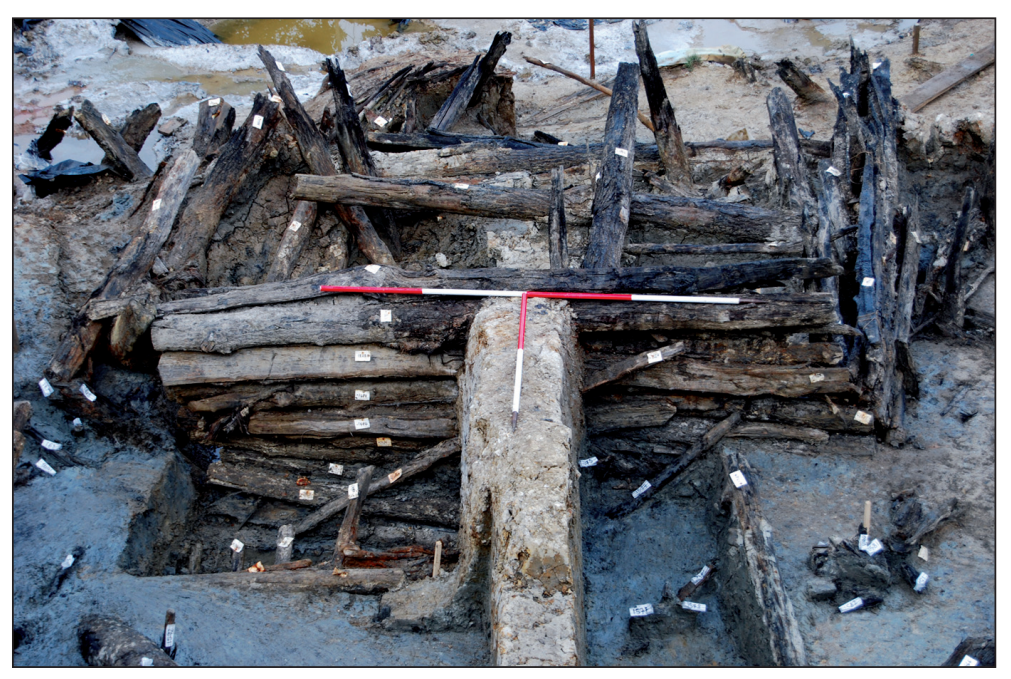

Fig. 5. Wood-lined shaft of Iron Age date at Băile Figa. 


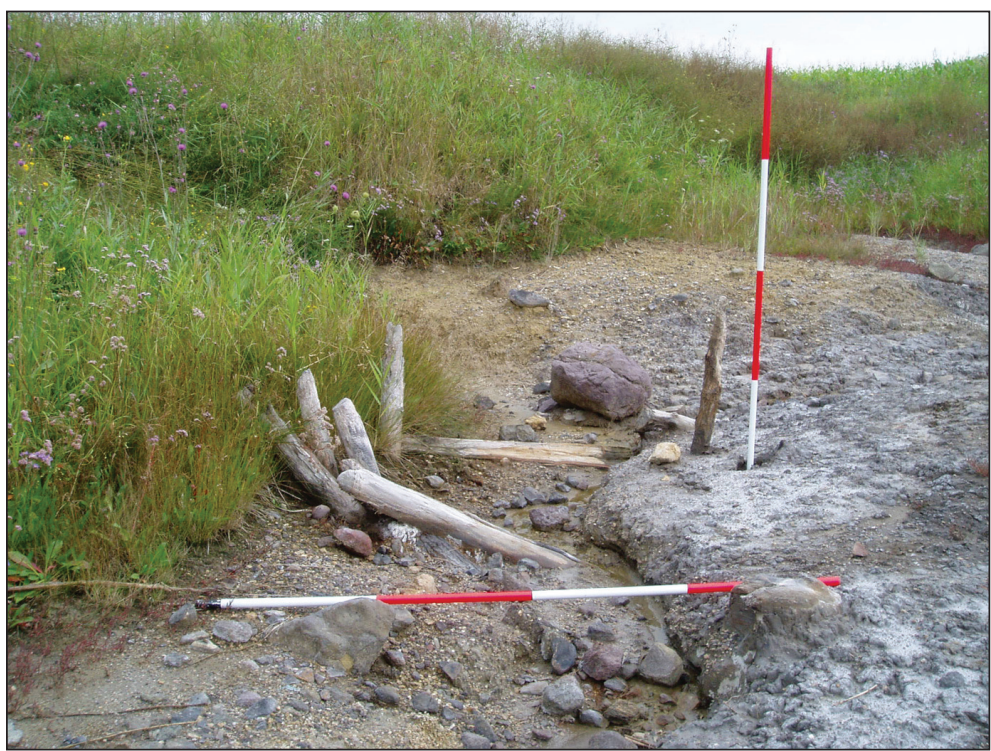

Fig. 6. Timbers in the salt stream at Sânpaul, Harghita county, Romania.

There was evidently a Roman saltworks at this place, though of the four radiocarbon dates obtained, three belong to the early modern period and one to the Iron Age. Clearly, the area was one of continuing and long-lasting activity, whatever the situation in the Roman period.

Elsewhere in Transylvania, the evidence for Roman salt production is again largely circumstantial, derived from the proximity of Roman sites to known salt sources, and from the presence of inscriptions recording similar conductores (Russu 1956). Mining technology, both for metal minerals and for salt, is extensively known in Dacia (Wollmann 1996), notably from such well-known mining areas as Roşia Montana in Alba county.

\section{The importance of salt in the prehistoric eco- nomy}

Salt was only one commodity in the range of materials that were exploited in the Carpathian Basin in prehistory; many would imagine that the metal minerals were more important than salt, since Transylvania is rich in such minerals, and must have supplied the metal-less Hungarian plain with them. Yet salt is easily underestimated as a desirable commodity, which people have traditionally gone to great lengths to acquire. As explained above, the unequal distribution of salt sources meant that an area like Transylvania would have been in a prime position to provide supplies to those without. But this raises the question of the scale of the operation at the production sites. Kavruk and I have considered the mat- ter in some detail (Harding, Kavruk 2013.209-217). In a Bronze Age context, when briquetage sites around Europe were relatively small, and in the Carpathian Basin more or less absent, we have argued that the scale of production on such sites was limited to the domestic sphere; the volumes were simply too small for anything else. With the massive installations uncovered in and near Transylvania, on the other hand, it is likely that the technology involved enabled many kilograms per day to be produced, which must mean that most of the salt was destined not for local consumption, but for transport to the salt-less areas to the west and south. Seen in this light, the salt production of at least this part of the Carpathian Basin takes on a new dimension. It becomes, like Hallstatt, a major producer of an essential commodity.

It is impossible at the moment to chart the movement of that salt to areas outside Transylvania. Salt is highly soluble and generally does not survive; only a couple of examples are known from prehistoric contexts, one from western Hungary (Németh 2013), probably emanating from Alpine sources, and the other from Crete (Kopaka, Chaniotakis 2003). Briquetage and coarse pottery containers were used in western Europe to transport salt in cake form, but not in central and eastern Europe, at least, not in the Bronze and Iron Ages. Any reconstruction of a salt trade must therefore depend on proxy sources, such as what is known from the medieval and modern salt trade (Marc 2006).

Even though the produced salt is effectively invisible archaeologically, we need be in no doubt about its importance in the prehistoric economy. It joins a number of other commodities, such as textiles or wooden handicrafts, for which we have to assume a presence without usually being able to demonstrate it. Given its known importance in historical times, for food preservation, for human and animal health, and for a range of industrial processes, salt can take its place as a major driver of commercial and technological enterprise in prehistory, just as it has in modern and historical periods. 


\section{References}

Andronic M. 1989. Cacica - un nou punct neolitic de exploatare a sării. Studii şi cercetări de istorie veche și arheologie 40(2): 171-177.

Bánffy E. 2013. Tracing $6^{\text {th }}-5^{\text {th }}$ millennium BC salt exploitation in the Carpathian Basin. In A. Harding, V. Kavruk (eds.), Explorations in Salt Archaeology in the Carpathian Zone. Archaeolingua. Budapest: 201-207.

Bukowski K. 2013. Salt sources and salt springs in the Carpathian zone. In A. Harding, V. Kavruk (eds.), Explorations in Salt Archaeology in the Carpathian Zone. Archaeolingua. Budapest: 27-34.

Buzea D. 2010. Experimentul, Troaca. Angustia 14: $245-$ 256.

Cavruc V., Buzea D. L., Kovács A. and Zăgreanu R. 2014. Cercetări arheologice efectuate la Băile Figa în anii 20132014. Secţiunea XV. Raport preliminar (Archaeological researches in the Băile Figa site in 2013-2014. Preliminary Report). Angustia 17-18: 151-180.

Chintăuan I. 2005. Pan used for salt extraction from brines. Studii si Cercetări, Geologie-Geografie 10: 75-78.

Harding A. 2011. Evidence for salt production rediscovered in the Hungarian Central Mining Museum. The Antiquaries Journal 91: 27-49.

Harding A., Kavruk V. (eds.) 2013. Explorations in Salt Archaeology in the Carpathian Zone. Archaeolingua. Budapest.

Jodłowski A. 1971. Eksploatacja sóli na terenie Małopolski $w$ pradziejach $i$ we wczesnym średniowieczu. Muzeum Żup Krakowskich. Studia i materiały do dziejów żup sólnych w Polsce. 4. Wieliczka.

Kern A., Kowarik K., Rausch A. W. and Reschreiter H. (eds.) 2009. Kingdom of Salt. 7000 years of Hallstatt (English version of Salz-Reich. 7000 Jahre Hallstatt, 2008). Veröffentlichungen der prähistorischen Abteilung 3. Naturhistorisches Museum. Vienna.

Kopaka K., Chaniotakis N. 2003. Just taste additive? Bronze Age salt from Zakros, Crete. Oxford Journal of Archaeo$\operatorname{logy} 22(1): 53-66$.

Marc D. 2006. Sisteme de transport şi de comercializare tradițională a sării. In V. Cavruc, A. Chiricescu (eds.), Sarea, Timpul şi Omul. Editura Angustia. Sfântu Gheorghe: 152-157.
Maxim I. A. 1971. Un depozit de unelte dacice pentru exploatarea sării. Acta Musei Napocensis 8: 457-463.

Monah D. 2002. L'exploitation préhistorique du sel dans les Carpathes orientales. In 0. Weller (ed.), Archéologie du sel: techniques et sociétés dans la pré- et protohistoire européenne. Salzarchäologie. Techniken und Gesellschaft in der Vor- und Frühgeschichte Europas. Verlag Marie Leidorf GmbH. Rahden/Westf.: 135-146.

Németh T. G. 2013. Angaben zum spätbronzezeitlichen Salzverkehr. In. B. Rezi, R. E. Németh and S. Berecki (eds.), Bronze Age Crafts and Craftsmen in the Carpathian Basin. Editura MEGA. Târgu Mureş: 57-63.

Piso I. 2004-2005 (2007). Un nouveau conductor salinarum en Dacie. Acta Musei Napocensis 41-42(1): 179-182.

Preisig E. 1877. Geschichte des Máramaroser Bergbaues. Österreichische Zeitschrift für Berg- und Hüttenwesen 25/28-30: 301-303, 311-313, 321-323.Tafel 12.

Russu I. I. 1956. Sclavul Atticus. Contributie la istoria economică a Daciei. Studii şi Cercetări de Istorie 7: 7-13.

Tasić N. 2002. Salt trade in the Neolithic of south-east Europe. In 0. Weller (ed.), Archéologie du sel: techniques et sociétés dans la pré-et protohistoire européenne. Salzarchäologie. Techniken und Gesellschaft in der Vor-und Frühgeschichte Europas. Marie Leidorf GmbH. Rahden/ Westf.: 147-152.

Ursulescu N. 1977. Exploatarea sării din saramura în neoliticul timpuriu în lumina descoperirilor de la Solca (jud. Suceava). Studii si cercetări de istorie veche 28(3): 307-317.

Vezetô 1909. Vezetô a Magyar Királyi Földtani Intézet Múzeumában. A Magyar Királyi Földtani Intézet népszerú kiadványai I. kötet. Az Intézet negyven éves fennállásának emlékére. Kiadja a Magyar Királyi Földmivelésügyi Minisztérium Fennhatsóga alá Tartozó M. Kir. Földtani Intézet. Budapest.

Wollmann V. 1996. Mineritul metalifer, extragerea sării şi carierele de piatră în Dacia Romană. / Der Erzbergbau, die Salzgewinnung und die Steinbrüche im Römischen Dakien. Bibliotheca Musei Napocensis 13. Veröffentlichungen aus dem Deutschen Bergbau-Museum Bochum 63. Muzeul Naţional de Istorie a Transilvaniei. ClujNapoca. 